\title{
Differential Effects of Angiotensin II on Intra-Renal Hemodynamics in Rats; Contribution of Prostanoids, NO and $\mathrm{K}^{+}$Channels
}

\author{
Ighodaro Igbe $^{1 *}$, Eric K. I. Omogbai ${ }^{1}$, Adebayo O. Oyekan ${ }^{2}$
}

${ }^{1}$ Department of Pharmacology and Toxicology, Faculty of Pharmacy, University of Benin, Benin City, Nigeria; ${ }^{2}$ Center for Cardiovascular Diseases, College of Pharmacy and Health Sciences, Texas Southern University, Houston, USA.

Email: *igbe.ighodaro@uniben.edu

Received May 22 $2^{\text {nd }}, 2012$; revised June $24^{\text {th }}, 2012$; accepted July $15^{\text {th }}, 2012$

\begin{abstract}
Many agents are known to cause qualitative and quantitative differences in intrarenal blood flow. This study tested the hypothesis that angiotensin II (AII) evokes a differential effect on cortical (CBF) and medullary blood flow (MBF) and that $\mathrm{AT}_{2}$ receptor mediates AII-induced increase in renal MBF by mechanisms related to nitric oxide (NO) and prostanoids. AII (100, 300 and $1000 \mu \mathrm{g} / \mathrm{kg} / \mathrm{min})$ increased mean arterial blood pressure (MABP) by $24 \% \pm 7 \%(\mathrm{p}<$ $0.05)$; decreased CBF by $30 \% \pm 2 \%(\mathrm{p}<0.05)$; but increased MBF by $21 \% \pm 8 \%(\mathrm{p}<0.05)$. Indomethacin $(5 \mathrm{mg} / \mathrm{kg})$, enhanced AII effects on MABP by $154 \% \pm 26 \%(\mathrm{p}<0.05)$, MBF by $141 \% \pm 46 \%$ but decreased CBF by $74 \% \pm 54 \%(\mathrm{p}<$ $0.05)$ indicating the involvement of dilator prostanoids in the systemic and medullary circulation but constrictor prostanoids in the cortex. $\mathrm{N}^{\mathrm{G}}$ nitro-L-arginine (L-NNA), an inhibitor of NO synthase (100 mg/L in drinking water) enhanced AII effects on MABP $(169 \pm 75, \mathrm{p}<0.05)$ and decreased CBF $(107 \% \pm 50 \%, \mathrm{p}<0.05)$ but blunted the effects of AII on MBF $(150 \% \pm 21 \%, \mathrm{p}<0.05)$. 1H-[1,2,4]oxadiazolo[4,3,-a]quinoxalin-1-one (ODQ; $2 \mathrm{mg} / \mathrm{kg}$ ), a guanylyl cyclase inhibitor, enhanced AII effects on MABP $(118 \% \pm 32 \%, \mathrm{p}<0.05)$ and decreased $\mathrm{CBF}(85 \% \pm 47 \%, \mathrm{p}<0.05)$ but blunted the effects of AII on MBF $(96 \% \pm 15 \%, \mathrm{p}<0.05)$. However, glibenclamide $(20 \mu \mathrm{g} / \mathrm{kg})$, a $\mathrm{K}_{\mathrm{ATP}}$ channel blocker, did not affect intra-renal hemodynamics elicited by AII. Blockade of $\mathrm{AT}_{2}$ receptors with PD123319 (50 $\mu \mathrm{g} / \mathrm{kg} / \mathrm{min}$ ) did not change basal or AII-induced changes MABP or CBF but blunted AII-induced increase in MBF by $60 \% \pm 11 \%(\mathrm{p}<0.05)$. CGP42112 $(10 \mu \mathrm{g} / \mathrm{kg} / \mathrm{min})$, an $\mathrm{AT}_{2}$ receptor agonist, elicited a reduction in MABP and increases in CBF and MBF that were abolished or attenuated by PD123319. These findings demonstrate that AII elicited differential changes in intrarenal blood flow; an $\mathrm{AT}_{1}$-mediated reduction in $\mathrm{CBF}$ but an $\mathrm{AT}_{2}$-mediated increase in $\mathrm{MBF}$. The $\mathrm{AT}_{2}$ receptor-mediated increase in MBF involves guanylase cyclase, $\mathrm{NO}$ and dilator prostanoids but not $\mathrm{K}_{\mathrm{ATP}}$ channels.
\end{abstract}

Keywords: Angiotensin II; Hemodynamics; Medullary Blood Flow; $\mathrm{AT}_{2}$ Receptors; Prostanoids

\section{Introduction}

The intrarenal vasculature can respond to neural and a variety of humoral stimuli with vasodilatation or vasoconstriction, resulting in increased or decreased perfusion of renal tissue, respectively [1]. Such responses may have more serious functional consequences within the medulla than in the cortex. This is of major physiological and pathophysiological importance as the medulla is widely viewed as having a crucial role in maintaining body fluid homeostasis and in the control of arterial pressure [2].

The renin-angiotensin system is a coordinated hormonal cascade important to the regulation of renal sodium excretion and blood pressure. The major effector peptide,

${ }^{*}$ Corresponding author. angiotensin II (AII), binds to two major receptors; $\mathrm{AT}_{1}$ and $\mathrm{AT}_{2}$. While the majority of AII actions are mediated via the $\mathrm{AT}_{1}$ receptor, evidence has accumulated that the $\mathrm{AT}_{2}$ receptor opposes the $\mathrm{AT}_{1}$ receptor, especially by inducing vasodilation instead of vasoconstriction and may be important in the regulation of blood pressure and renal function by counterbalancing the vasoconstrictor and antinatriuretic actions of $\mathrm{AT}_{1}$ receptors [3]. However, the roles of $\mathrm{AT}_{1}$ and $\mathrm{AT}_{2}$ receptors in regulating regional kidney perfusion remain unclear. In rats and rabbits, infusions of AII reduced total renal blood flow (RBF) and cortical blood flow but have a lesser effect on medullary blood flow $[4,5]$. AII can even increase MBF, especially when administered as a bolus [1,6]. Many studies have demonstrated that the medullary vasculature was poorly sensitive to the vasoconstrictor effects of AII 
compared with the cortical circulation $[4,7,8]$. A study [9] has shown that AII induced a potent vasoconstriction of isolated medullary vasa recta in Sprague-Dawley rats, a response also observed in conscious rats [10]. Conversely, other studies have shown that the systemic infusion of AII increased papillary blood flow in young SpragueDawley and Wistar rats [11] by increasing local medullary synthesis of vasodilator agents such as prostaglandins, nitric oxide (NO), or kinins.

Nitric oxide (NO) synthase and/or cyclooxygenase (COX) blockade can enhance AII-induced reductions in medullary blood flow (MBF) and abolish AII-induced increases in MBF, both of which are chiefly $\mathrm{AT}_{1}$ mediated [12-14]. However, the contributions of $\mathrm{AT}_{2}$ receptors to these effects have received little attention, even though they are expressed in vessels that might contribute to MBF control (e.g., afferent arterioles and vasa recta). In a routine experiment to address the effects of AII in the rat, we noticed a differential effect on CBF and MBF and this led us to characterize these effects. We hypothesized that AII evokes a differential effect on intrarenal hemodynamics by an $\mathrm{AT}_{1}$-mediated cortical vasoconstriction but $\mathrm{AT}_{2}$ receptor-mediated increase in renal medullary blood flow. To test this hypothesis, mean arterial blood pressure (MABP), MBF and CBF responses to graded doses of AII were determined in the presence of indomethacin, $N^{\omega}$-nitro-L-arginine, ODQ $(1 \mathrm{H}-[1,2,4]$ oxadiazolo[4,3,-a]quinoxalin-1-one), or glibenclamide. In addition, we characterized the increase in MBF using

CGP42112, a highly selective $\mathrm{AT}_{2}$ agonist, and PD123319, an $\mathrm{AT}_{2}$ antagonist.

\section{Materials and Methods}

\subsection{Drugs and Chemicals}

$N^{\omega}$-nitro-L-arginine (L-NNA;Sigma-Aldrich, St. Louis, MO) and indomethacin (Sigma-Aldrich, St. Louis, MO) were dissolved in $0.1 \mathrm{M} \mathrm{NaHCO}_{3}$, and $\mathrm{pH}$ was adjusted to 7.0 - 7.2. Glibenclamide (Sigma-Aldrich, St. Louis, MO) and 1H-[1,2,4]oxadiazolo[4,3,-a]quinoxalin-1-one (ODQ; Sigma-Aldrich, St. Louis, MO) were prepared in dimethylsulfoxide (DMSO) as stock solutions of $0.1 \mathrm{M}$, from which aliquots were diluted in normal saline for intravenous administration. Angiotensin II (Sigma-Aldrich), CGP42112 (21st Century Biochemicals, USA) and

PD123319 (a gift from Park Davis, USA) were dissolved in normal saline $(0.9 \% \mathrm{NaCl})$. All agents were kept on ice during the experiments.

Female Sprague-Dawley rats (230 - 290 g body wt; Harlan Sprague Dawley, Houston, TX) were maintained on standard rat food (Purina Chow; Purina, St Louis, MO) and allowed ad libitum access to water and food until the beginning of the experiments. The study protocol was approved by the Animal Care and Use Committee of Texas Southern University.

\subsection{Surgical Preparation}

Animals were anesthetised with thiobutabarbital (Inactin), $100 \mathrm{mg} / \mathrm{kg}$ ip (Sigma-Aldrich) and placed on a heated surgical table to maintain body temperature at $37^{\circ} \mathrm{C}$. The tail vein was cannulated with a 25 -gauge butterfly needle (Vacutainer, Becton and Dickson) for infusion or administration of drugs. The trachea was isolated and a polyethylene catheter (PE-250) was placed in the trachea for spontaneous ventilation. A polyethylene catheter (PE-50) was placed in the left carotid artery to monitor the blood pressure. Mean arterial blood pressure (MABP) was measured with a pressure transducer (model BLPR2, World Precision Instruments, Sarasota, FL) to a signal manifold (Transbridge, model TBM-4, World Precision Instrument, Sarasota, FL) and recorded on a data acquisition system (model DI720, DataQ Instruments, Akron, $\mathrm{OH})$. The left kidney was exposed by an abdominal incision, intrarenal blood flow was measured simultaneously by laser-Doppler (LD) flowmeter (system 5000, version 1.20, Periflux, Stockholm, Sweden) via a surface probe (model PF 407) to measure CBF or an optical fiber LD probe (model PF 402) fixed to a micromanipulator and placed in the medulla $(5 \mathrm{~mm}$ below the kidney surface) to measure MBF. CBF and MBF were recorded as perfusion units (PU).

\subsection{Experimental Protocol}

After surgery and placing of probes for recording regional blood flows, a 30- to 45-min equilibration period was allowed. AII was administered by an infusion pump (Model 100, SP 100i syringe pump, WPI, USA) at graded doses of 100,300 and $1000 \mathrm{ng} / \mathrm{kg} / \mathrm{min}$. These graded doses were administered cumulatively. The effects on MABP, $\mathrm{CBF}$ and MBF were determined in the presence of indomethacin, a COX inhibitor $(10 \mathrm{mg} / \mathrm{kg}$ iv; $\mathrm{n}=6)$ [15], L-NNA, $N^{\omega}$-nitro-L-arginine, a NO synthase inhibitor $(100 \mathrm{mg} / \mathrm{L}$ in drinking water for 2 days; $\mathrm{n}=6)$ [16], ODQ, 1H-[1,2,4]oxadiazolo[4,3,-a]quinoxalin-1one, a guanylase cyclase inhibitor $(2 \mathrm{mg} / \mathrm{kg}$ iv; $\mathrm{n}=5)$ [17], glibenclamide, a $\mathrm{K}_{\mathrm{ATP}}$ channel blocker $(20 \mu \mathrm{g} / \mathrm{kg}$, iv) [18]; or their respective vehicles: $0.1 \mathrm{M} \mathrm{NaHCO}_{3}$ for L-NNA and indomethacin, 5\% DMSO for glibenclamide and ODQ and normal saline for AII. Data obtained from rats treated with $5 \% \mathrm{DMSO}$ and $0.1 \mathrm{M} \mathrm{NaHCO}_{3}$ were not different from those obtained from rats treated with normal saline; hence, data from both groups were pooled to represent control data for all the treatment groups.

Another set of experiments to characterize the possible mechanisms involved in AII-induced increase in MBF 
was carried out. MABP, MBF and $\mathrm{CBF}$ responses to graded doses of AII were determined in the presence of CGP42114, an $\mathrm{AT}_{2}$ receptor agonist and PD123319, an $\mathrm{AT}_{2}$ receptor antagonist. Animals were anesthetized and the left carotid artery cannulated for MABP determination while intrarenal blood flow was measured simultaneously by a laser-Doppler (LD) flow meter. After recording baseline values, the effects of CGP42114 $(10 \mu \mathrm{g} / \mathrm{kg} / \mathrm{min}$; $\mathrm{n}=5$ ) were evaluated on MABP, CBF and MBF at intervals of 5, 10, 15 and $20 \mathrm{~min}$. After infusion was stopped, a $30 \mathrm{~min}$ interval was allowed for the values to return to baseline. $\mathrm{PD} 123319$, an $\mathrm{AT}_{2}$ receptor antagonist was infused at $50 \mu \mathrm{g} / \mathrm{kg} / \mathrm{min}$ [19] for $10 \mathrm{~min}$ before CGP42112 $(10 \mu \mathrm{g} / \mathrm{kg} / \mathrm{min})$ was infused concurrently and the antagonistic effect of PD123319 was determined at intervals of 5, 10, 15 and 20 min. Doses of all agents used were those reported in the literature to produce significant desired effects.

\subsection{Statistical Analysis}

All data were expressed as mean \pm SEM. Changes in systemic and renal hemodynamics were expressed as absolute values and changes from baseline. The effects of a particular agent were analysed using a two-way ANOVA followed by Tukey's multiple comparison test when appropriate. Statistical analysis was performed using Graph Pad Prism V. 4.01 where $p<0.05$ was considered statistically significant.

\section{Results}

\subsection{Effect of Angiotensin II Infusion on Systemic and Renal Haemodynamics}

Figure 1(a) shows a representative tracing illustrating the differential effect of AII on systemic and renal haemodynamics. AII (300 and $1000 \mathrm{ng} / \mathrm{kg} / \mathrm{min})$ increased mean arterial blood pressure (MABP) and medullary blood flow (MBF) while decreasing renal cortical blood flow $(\mathrm{CBF})$ in a dose related manner. AII (300 and 1000 $\mathrm{ng} / \mathrm{kg} / \mathrm{min}$ ) increased mean arterial blood pressure (MABP) by $24 \pm 5$, and $47 \pm 7 \mathrm{mmHg}$; decreased renal cortical blood flow (CBF) by $-202 \pm 69$ and $-98 \pm 81$ perfusion units (PU), but increased medullary blood flow (MBF) by $17 \pm 09$ and $53 \pm 14 \mathrm{PU}$ respectively.

\subsection{Effect of Angiotensin II Infusion on Systemic and Renal Haemodynamics in the Presence of Indomethacin, L-NNA, ODQ and Glibenclamide}

Figure 2 illustrates that AII (100, 300 and $1000 \mathrm{ng} / \mathrm{kg} / \mathrm{min})$ dose-dependently increased MABP by $13 \pm 4,22 \pm 6$, and $49 \pm 8 \mathrm{mmHg}$, respectively; decreased $\mathrm{CBF}$ by $-116 \pm$

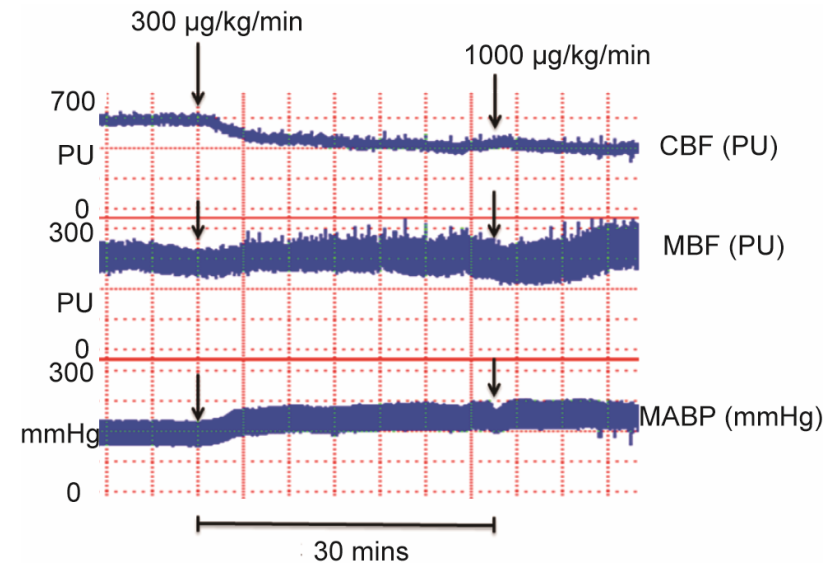

(a)

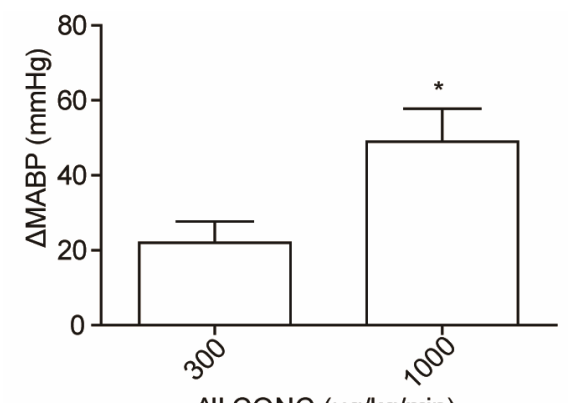

Al CONC $(\mu \mathrm{g} / \mathrm{kg} / \mathrm{min})$
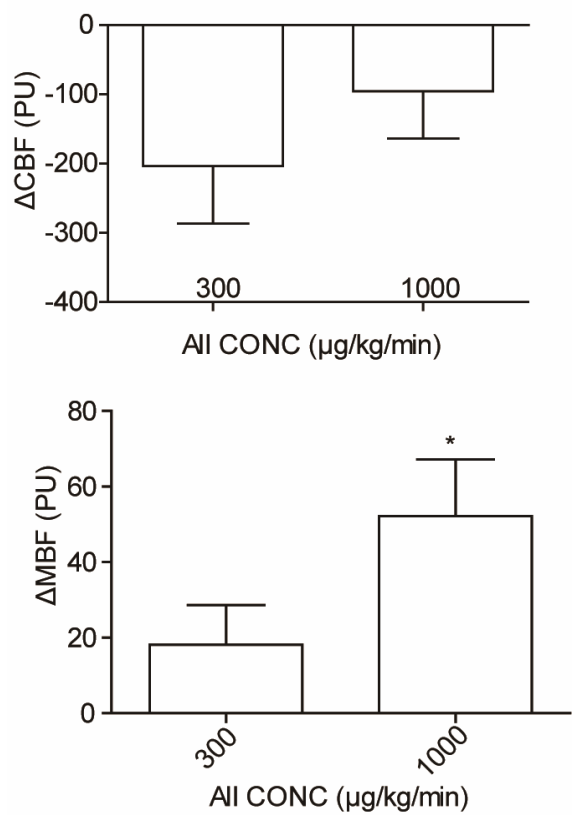

(b)

Figure 1. (a) Tracing showing the differential effects of angiotensin II (AII) on systemic (MABP) and renal hemodynamics (CBF \& MBF). MABP = mean arterial blood pressure, $\mathrm{MBF}=$ medullary blood flow, $\mathrm{CBF}=$ cortical blood flow; (b) Graphical illustration showing the differential effects of angiotensin II (AII) on systemic (MABP) and renal hemodynamics (CBF \& MBF). ( ${ }^{*}$ p $<0.05$ vs 300 $\mathbf{n g} / \mathbf{k g} / \mathbf{m i n}$ of AII). 


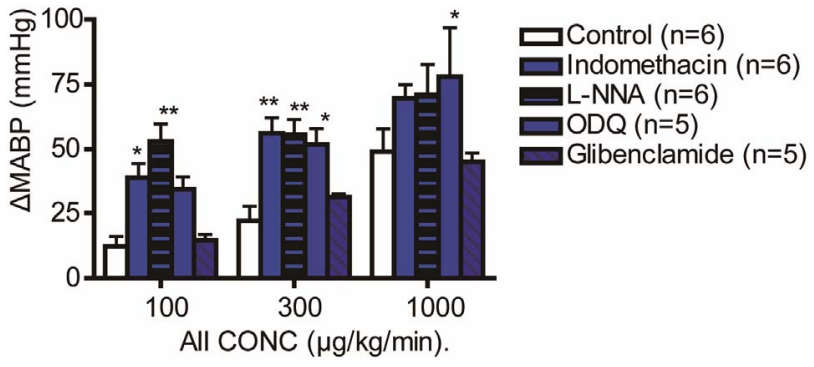

(a)

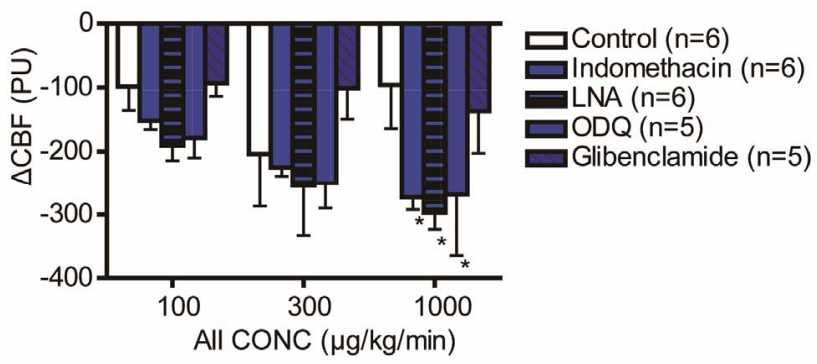

(b)

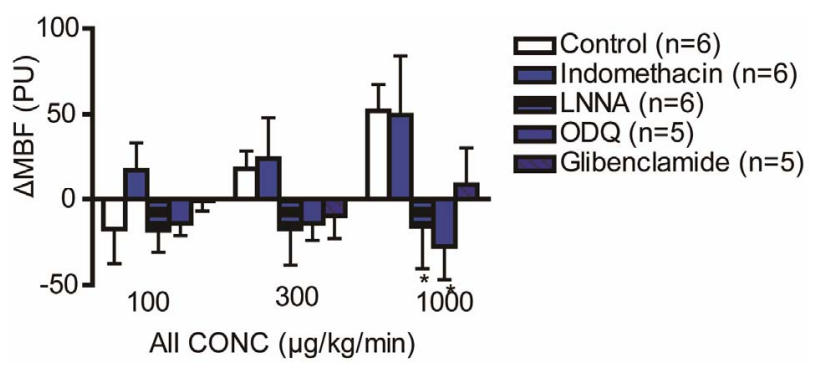

(c)

Figure 2. Effect of acute angiotensin II infusion on systemic (a) and renal (b), (c) haemodynamics in the presence of indomethacin, L-NNA, ODQ or glibenclamide ( ${ }^{*} \mathrm{p}<0.05$, ${ }^{* *} \mathbf{p}<\mathbf{0 . 0 1}$ vs Control).

$42,-204 \pm 83$ and $-96 \pm 67$ perfusion units (PU), respectively but increased MBF by $18 \pm 10$ and $52 \pm 15 \mathrm{PU}$ respectively. Indomethacin $(10 \mathrm{mg} / \mathrm{kg})$ enhanced AIIinduced increase in MABP by $154 \% \pm 26 \%(\mathrm{p}<0.05)$, decreased CBF by $74 \% \pm 54 \%(\mathrm{p}<0.05)$ and increased AII-induced increase in MBF by $141 \% \pm 46 \%(\mathrm{p}<0.05)$ indicating that vasodilator prostaglandins may be contributing to the increase in MBF while the vasoconstrictor prostaglandins may be contributing to the increase in MABP or decrease in CBF elicited by AII. $\mathrm{N}^{\mathrm{G}}$ nitro-L-arginine (L-NNA; $100 \mathrm{mg} / \mathrm{L}$ in drinking water for 2 days) enhanced AII-induced increase in MABP by $169 \pm 75(\mathrm{p}<0.05)$ and decrease in CBF by $107 \pm 50(\mathrm{p}<$ 0.05 ) but blunted the effects of AII on MBF by $150 \pm 21$ $(\mathrm{p}<0.05)$. ODQ, a soluble guanylyl cyclase $(\mathrm{sGC} ; 2$ $\mathrm{mg} / \mathrm{kg}$ ) inhibitor, enhanced AII-induced increase in MABP by $118 \% \pm 32 \%(\mathrm{p}<0.05)$ and decrease in CBF by $85 \% \pm 47 \%(\mathrm{p}<0.05)$ but blunted the effects of AII on MBF by $96 \% \pm 15 \%(\mathrm{p}<0.05)$. This indicates that
NO and activation sGC contribute to the AII-induced increase in $\mathrm{MBF}$ or decrease in $\mathrm{CBF}$. However, in the presence of glibenclamide there were no significant changes in AII-induced increase in MABP and MBF or decrease in $\mathrm{CBF}$ as compared to the control, thus indicating that $\mathrm{K}_{\mathrm{ATP}}^{+}$channels are not involved in AII-induced increase in $\mathrm{MBF}$.

\subsection{Effect of Angiotensin II Infusion on Systemic and Renal Haemodynamics as Affected by $\mathrm{AT}_{2}$ Receptor Antagonism}

The involvement of $\mathrm{AT}_{2}$ receptors in AII-induced changes in intrarenal haemodynamics, AII (100, 300 and 1000 $\mathrm{ng} / \mathrm{kg} / \mathrm{min}$ ) was infused in the presence of PD123319, an $\mathrm{AT}_{2}$ receptor antagonist. PD123319 $(50 \mu \mathrm{g} / \mathrm{kg} / \mathrm{min}) \mathrm{did}$ not change basal or AII-induced changes $\mathrm{BP}$ or $\mathrm{CBF}$. However, PD123319 blunted AII-induced increase in MBF by $60 \% \pm 11 \%(p<0.05)$ (Figures 3 and 4) indicating the involvement of $\mathrm{AT}_{2}$ receptors in AII-induced increase in MBF.

\subsection{Effect of CGP42112 Alone and in Combination with PD123319 on Basal Systemic and Renal Haemodynamics}

As an additional evidence to support that activation of $\mathrm{AT}_{2}$ receptor was responsible for AII-mediated increase in $\mathrm{MBF}$, the effects of CGP42112, an $\mathrm{AT}_{2}$ receptor agonist, was tested on basal systemic and renal haemo-dynamics in the presence or absence of PD123319. Figure 5

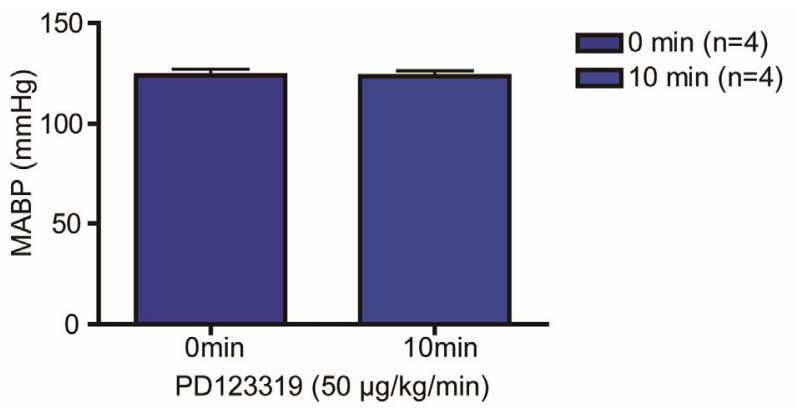

(a)

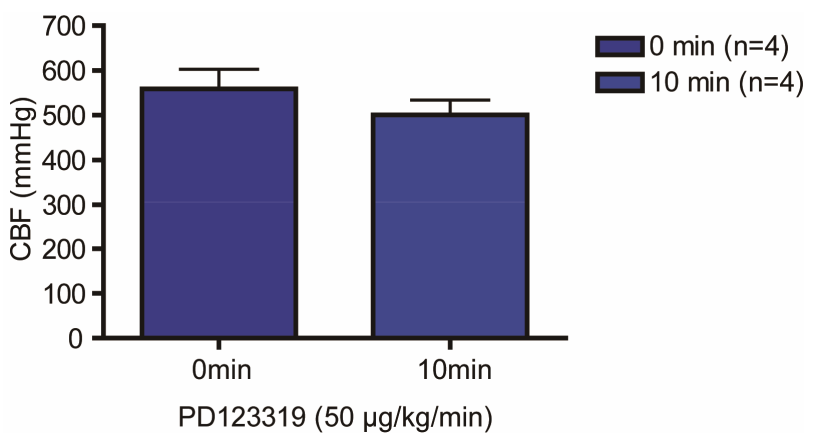

(b) 


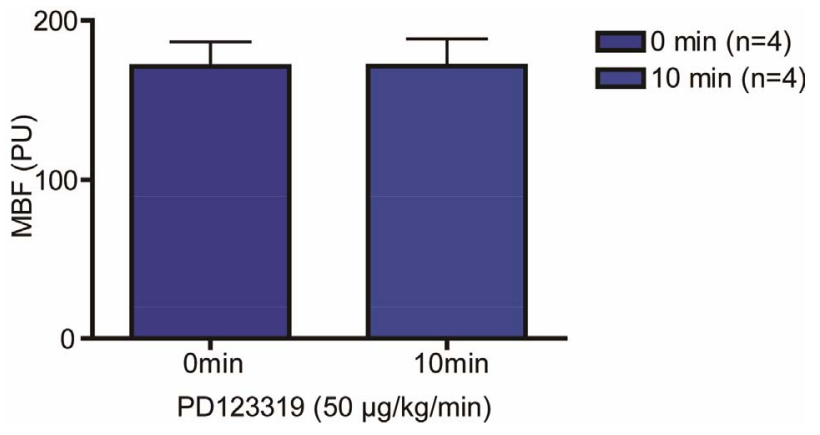

(c)

Figure 3. Effect of PD123319 on basal systemic (a) and renal (b), (c) haemodynamics. 0 min represents basal values while $10 \mathrm{~min}$ represents values obtained after infusion of PD 123319 (50 $\mu \mathrm{g} / \mathrm{kg} / \mathrm{min})$ for $10 \mathrm{~min}$. illustrates that CGP42112 decreased basal MABP, increased basal medullary perfusion and $\mathrm{CBF}$ in a timedependent manner. PD123319, $\mathrm{AT}_{2}$ receptor antagonist, attenuated CGP42112-induced decrease in MABP by $121 \% \pm 13 \%(\mathrm{p}<0.05)$, and CGP42112 induced increase in CBF by $142 \% \pm 3 \%(\mathrm{p}<0.01)$. CGP42112-induced increase in basal MBF was also blunted by PD123319 by $67 \% \pm 6 \%$. These data imply that $\mathrm{AT}_{2}$ receptor activation accounts for the increase renal MBF by AII.

\section{Discussion}

There is still considerable controversy regarding the relative effects of angiotensin II on CBF and MBF in anaesthetized animals perhaps reflecting a species de pendency. Thus, studies in dogs indicated that both
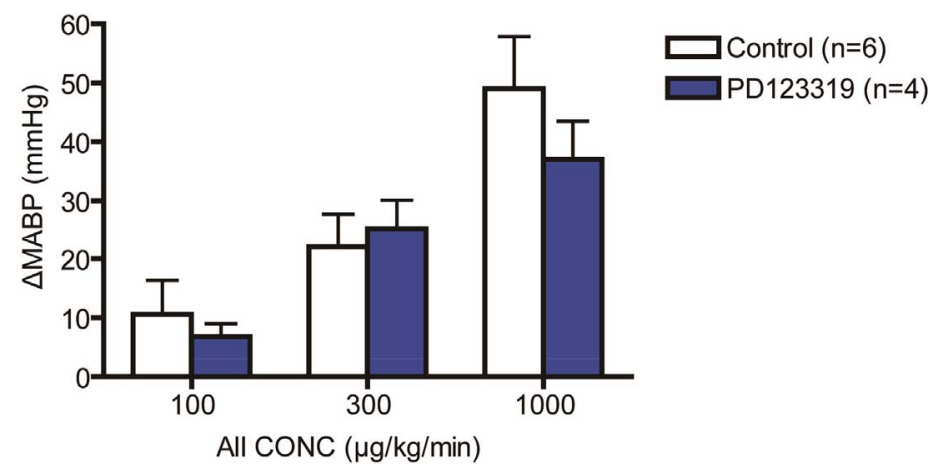

(a)

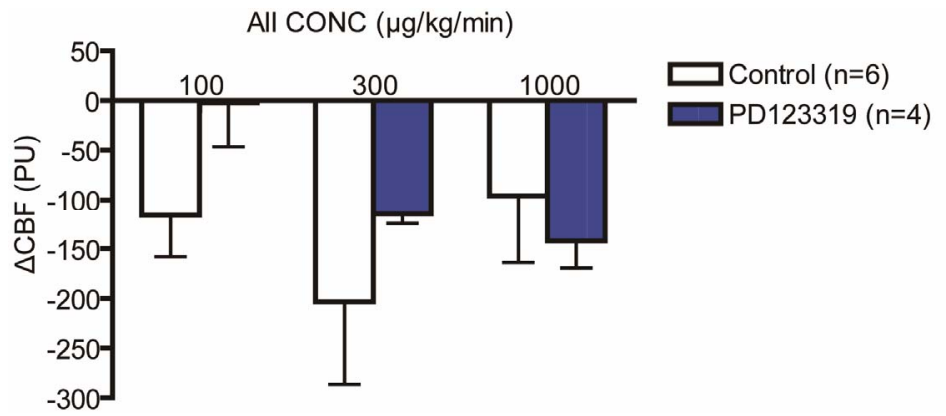

(b)

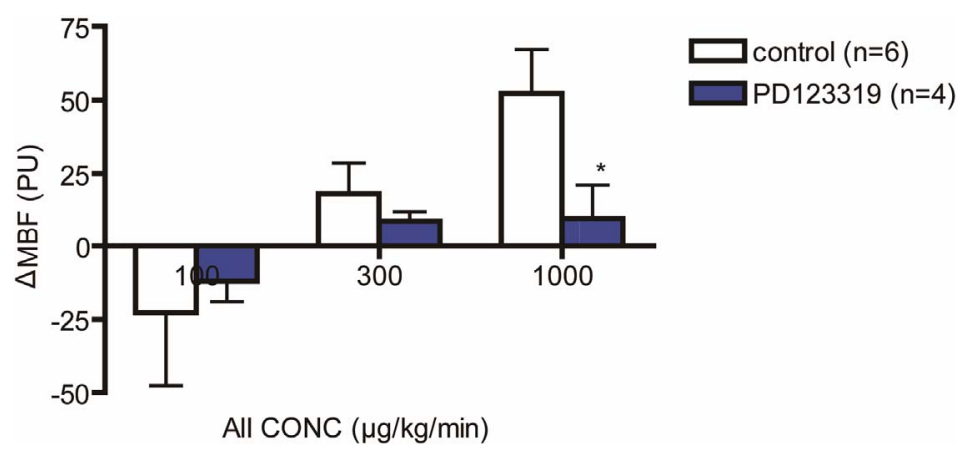

(c)

Figure 4. Effect of acute angiotensin II infusion on systemic (a) and renal (b), (c) haemodynamics in the presence of PD123319 ( ${ }^{*} \mathrm{p}<0.05$ vs control). Control animals were infused with normal saline $(1 \mathrm{~mL} / \mathrm{h})$. 


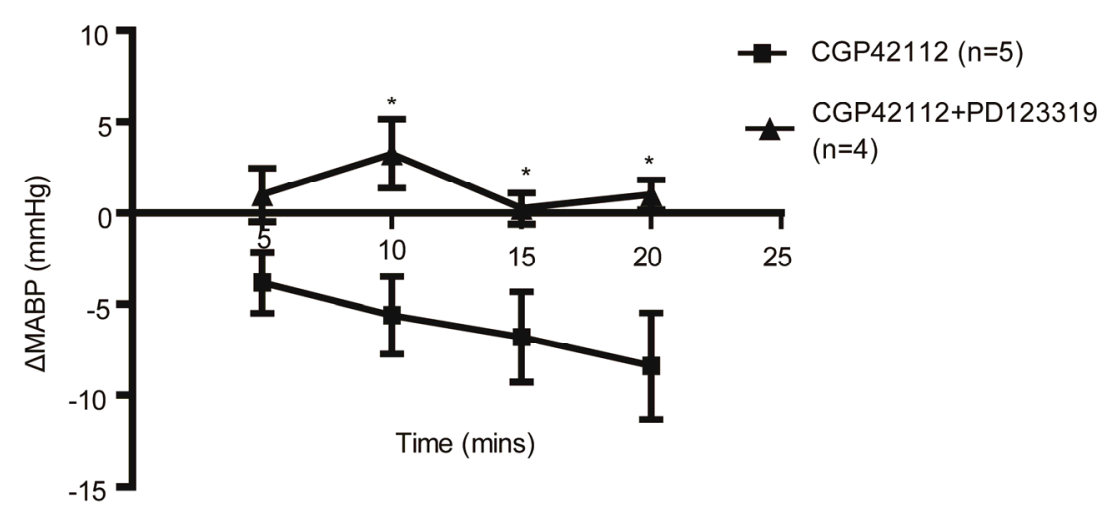

(a)

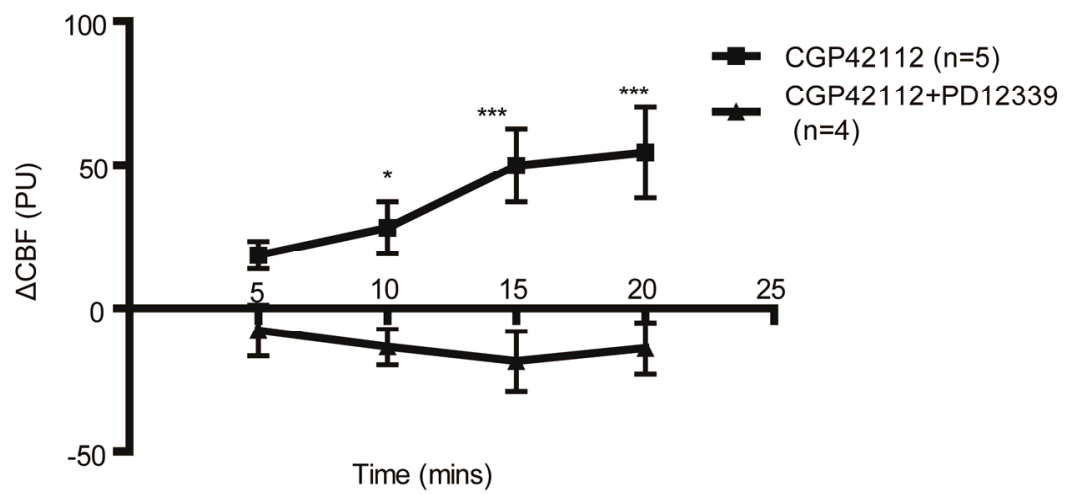

(b)

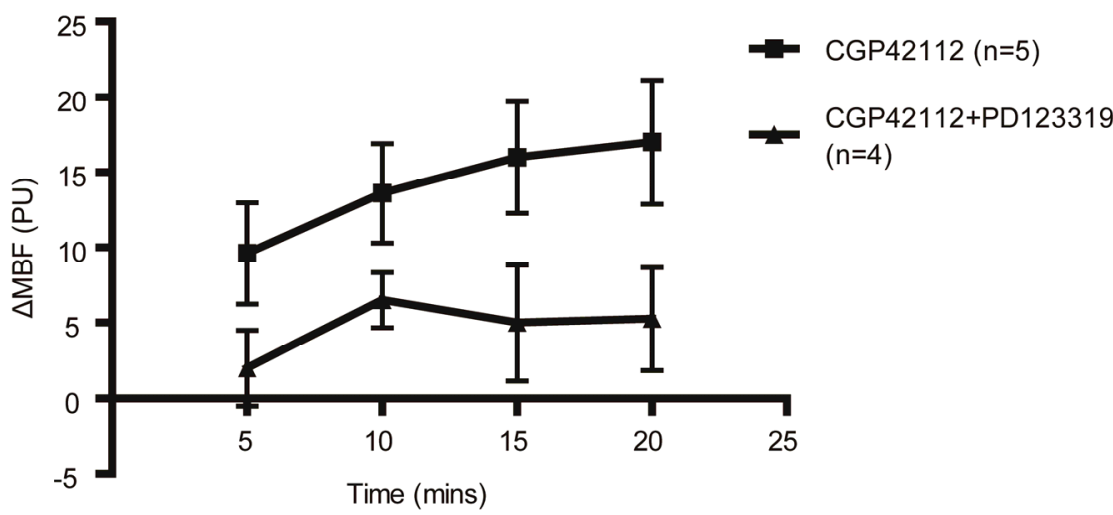

(c)

Figure 5. Effect of CGP42112 (10 $\mathrm{\mu g} / \mathrm{kg} / \mathrm{min})$ alone and in combination with PD123319 (50 $\mathrm{\mu g} / \mathrm{kg} / \mathrm{min})$ on basal systemic (a) renal (b), (c) haemodynamics ( $\left(^{*} \mathrm{p}<0.05,{ }^{* *}\right.$ p $<0.01$ vs CGP42112 + PD123319).

exogenous and endogenous angiotensin II profoundly increase MBF, even at levels that have little impact on CBF $[20,22]$. In contrast, in most studies in anaesthetized rats and rabbits, intravenous or renal arterial infusion of angiotensin II significantly decreased CBF but not MBF $[11,23,24]$.

In the present study, we tested the hypothesis that AII evokes a differential effect on intrarenal hemodynamics and that the $\mathrm{AT}_{2}$ receptor mediates the increase in the renal medullary blood flow during acute AII infusion in rats. Infusion of AII increased MABP and MBF dose dependently with associated decrease in CBF. The pressor and renal cortical vasoconstriction is a result of the vasoconstrictive effect of AII [25] probably mediated through $\mathrm{AT}_{1}$ receptors. Several studies have shown the paradoxical increase in MBF with AII bolus dose $[1,19]$. AII-induced vasodilatation, as seen in the medulla, could also have been indirect, being dependent on stimulation on the biosynthesis and/or release of vasodilator agents, such as prostaglandins, kinins or NO [26]. In order to determine which of the vasodilatory agents was involved in AII-induced increase in MBF, we examined the effect 
of AII infusion in the presence of indomethacin, a COX inhibitor, L-NNA, a NO synthase inhibitor, ODQ, a sGC inhibitor or glibenclamide, a $\mathrm{K}_{\mathrm{ATP}}$ channels blocker. LNNA or ODQ enhanced AII-induced increase in MABP and decrease in CBF but remarkably inhibited AIIinduced increase in MBF. This is in agreement with the studies that showed that inhibition of NO synthesis prevented an increase in perfusion of the medulla after AII $[14,27]$. NO acts through the stimulation of sGC, with subsequent formation of cyclic GMP. These findings implicate $\mathrm{NO}$ involvement via $\mathrm{sGC}$ in the increase in MBF induced by AII. These data are in agreement with previous studies [14,27,28]. The rate of synthesis and tissue concentration of prostaglandins is much higher in the medulla compared with the cortex, and AII stimulates prostaglandin synthesis via $\mathrm{AT}_{1}$ receptors [28]. Prostaglandin $\mathrm{E}_{2}\left(\mathrm{PGE}_{2}\right)$ is a major renal cyclooxygenase metabolite of arachidonate that modulates renal hemodynamics and salt and water excretion [29]. The maintenance of normal renal blood flow and function during physiological stress is especially dependent on endogenous prostaglandin synthesis [30] buffering the vasoconstrictor effects of AII, catecholamines, and vasopressin in the kidney thereby preserving normal renal function. Contrary to previous reports showing a tonic vasodilator influence of prostaglandins on the medullary circulation [31-33] inhibition of prostaglandins by indomethacin in this study enhanced AII-induced increase in MBF. This result suggests that vasodilator prostaglandins may be contributing to the increase in MBF while the vasoconstrictor prostaglandins may be contributing to the increase in MABP or decrease in CBF elicited by AII.

$\mathrm{K}_{\mathrm{ATP}}$ channel regulation of vasoactivity in vascular beds has been documented and infusion of glibenclamide, a $\mathrm{K}_{\mathrm{ATP}}$ into rats induced mesenteric, skeletal muscle, and renal vasoconstriction $[34,35]$. In vivo, $\mathrm{K}_{\mathrm{ATP}}$ channel inhibition also increases resistance to blood flow in mesentery [36], renal cortex and medulla [32,37]. Previous studies demonstrated that high concentrations of AII inhibit $\mathrm{K}_{\text {ATP }}$ in the renal medulla [38] and infusions of $\mathrm{K}_{\mathrm{ATP}}$ channel inhibitors have been shown to decrease MBF [15,32]. In the present studies, inhibition of $K_{\text {ATP }}$ channels with glibenclamide did not significantly change AII-mediated effects on systemic and renal hemodynamics.

AII acts at two main receptor subtypes: $\mathrm{AT}_{1}$ and $\mathrm{AT}_{2}$ receptors. $\mathrm{AT}_{1}$ receptors are responsible for mediating most of the known actions of AII, including vasoconstriction [39]. Moreover, a role for the $\mathrm{AT}_{2}$ receptor in opposing the actions of $\mathrm{AT}_{1}$ receptor stimulation has been implicated in growth and cardiovascular function [39-41]. In the kidney, infusions of AII reduce total renal blood flow (RBF) and cortical perfusion measured by laser Doppler flowmetry in rats and rabbits [41]. However, medullary perfusion is relatively insensitive to the vasoconstrictor effects of AII under most experimental conditions $[1,23]$. The explanation for these observations seems to be that, although $\mathrm{AT}_{1}$-receptor activation causes vasoconstriction within vascular elements controlling $\mathrm{MBF}$, it can also cause vasodilatation by release of nitric oxide and/or prostaglandins [5]. The contributions of $\mathrm{AT}_{2}$ receptors to the control of $\mathrm{MBF}$ are less clear. However, recent studies in anaesthetised rabbits suggest that $\mathrm{AT}_{2}$-receptor activation counteracts $\mathrm{AT}_{1}$-mediated vasodilatation in the renal medulla, as the $\mathrm{AT}_{2}$ antagonist PD123319 revealed dose-dependent increases in Medullary Laser Doppler Flux (MLDF) during renal arterial infusion of AII [19] implying an $\mathrm{AT}_{2}$-mediated medullary vasoconstriction but $\mathrm{AT}_{1}$-mediated vasodilation in the rabbit. This observation is at odds with the current study and contrary to the conventional view that $\mathrm{AT}_{2}$ receptors mediate vasodilatation [42]. In our studies, blockade of $\mathrm{AT}_{2}$ receptors with PD123319 attenuated AII-induced increase in $\mathrm{MBF}$, suggesting that the increase in MBF was $\mathrm{AT}_{2}$ receptor mediated. These data were further confirmed by infusion of CGP41112, an $\mathrm{AT}_{2}$ receptor agonist in the absence and presence of PD123319 to determine the effect of $\mathrm{AT}_{2}$ receptor on basal MABP, $\mathrm{CBF}$ and MBF. PD123319 had no detectable effect on resting systemic or renal hemodynamics. Thus, $\mathrm{AT}_{2}$ receptors did not appear to contribute greatly to the control of resting MBF in anesthetized rats under these experimental conditions. Activation of $\mathrm{AT}_{2}$ receptor by CGP41112 decreased basal MABP while increasing $\mathrm{CBF}$ and MBF. These responses were attenuated by PD123319, confirming that $\mathrm{AT}_{2}$ receptor is not only involved in increasing MBF but also appears to be involved in the increase in CBF and decrease in MABP. These data are at odds with studies that showed that the increased medullary perfusion was $\mathrm{AT}_{1}$ receptor-mediated $[1,6,19]$ in rats.

In conclusion, AII evoked differential effects on intrarenal haemodynamics in the rat evoking cortical vasoconstriction but medullary vasodilation. $\mathrm{AT}_{2}$ re-ceptor appears to mediate AII-induced increase in MBF by mechanisms involving guanylase cyclase, nitric oxide and dilator prostanoids but not $\mathrm{K}_{\text {ATP }}$ channels.

\section{Acknowledgements}

This study was supported by National Institutes of Health grant HL03674. The facilities of the RCMI program at Texas Southern University were used for this study.

\section{REFERENCES}

[1] B. Badzyńska, M. Grzelec-Mojzesowicz, L. Dobrowolski, and J. Sadowski, "Differential Effect of Angiotensin II on Blood Circulation in the Renal Medulla and Cortex of Anaesthetised Rats," Journal of Physiology, Vol. 538, No. 
1, 2002, pp. 159-166. doi:10.1113/jphysiol.2001.012921

[2] A. W. Cowley, "Role of the Renal Medulla in Volume and Arterial Blood Pressure Regulation," American Journal of Physiology, Vol. 273, No. 1, 1997, pp. R1-R15.

[3] R. M. Carey, "Update on the Role of the AT2 Receptor," Current Opinion in Nephrology and Hypertension, Vol. 14 , No. 1, 2005, pp. 67-71. doi:10.1097/00041552-200501000-00011

[4] W. A. Cupples, T. Sakai and D. J. Marsh, "Angiotensin II and Prostaglandins in Control of Vasa Recta Blood Flow," American Journal of Physiology, Vol. 254, No. 3, 1988, pp. F417-F424.

[5] R. G. Evans, A. C. Madden and K. M. Denton, "Diversity of Responses of Renal Cortical and Medullary Blood Flow to Vasoconstrictors in Conscious Rabbits," Acta Physiology Scandinavia, Vol. 169, No. 4, 2000, pp. 297-308. doi:10.1046/j.1365-201x.2000.00741.x

[6] L. L. Walker, A. A. Rajaratne, J. R. Blair-West and P. J. Harris, "The Effects of Angiotensin II on Blood Perfusion in the Rat Renal Papilla," Journal of Physiology, Vol. 519, No. 1, 1999, pp. 273-278. doi:10.1111/j.1469-7793.1999.02730.x

[7] D. L. Mattson, H. Raff and R. J. Roman, "Influence of Angiotensin II on Pressure Natriuresis and Renal Hemodynamics in Volume Expanded Rats," American Journal of Physiology: Regulatory, Integrative and Comparative Physiology, Vol. 260, No. 6, 1991, pp. R1200-R1209.

[8] C. L. Huang, G. Davis and E. J. Johns, "A Study of the Action of Angiotensin II on Perfusion through the Cortex and Papilla of the Rat Kidney," Experimental Physiology, Vol. 76, No. 5, 1991, pp. 787-798.

[9] T. L. Pallone, C. R. Robertson and R. L. Jamison, "Renal Medullary Microcirculation," Physiological Reviews, Vol. 70, No. 3, 1990, pp. 885-920.

[10] S. Lu, D. L. Mattson, R. J. Roman, C. G. Becker and A. W. Cowley Jr., "Assessment of Changes in Intrarenal Blood Flow in Conscious Rats Using Laser-Doppler Flowmetry," American Journal of Physiology Renal Fluid Electrolyte Physiology, Vol. 264, No. 2, 1993, pp. F956F962.

[11] M. S. Nobes, P. J. Harris, H. Yamada and F. A. O. Mendelsohn, "Effects of Angiotensin on Renal Cortical and Papillary Blood Flows Measured by Laser-Doppler Flowmetry," American Journal of Physiology Renal Fluid Electrolyte Physiology, Vol. 261, No. 6, 1991, pp. F998F1006.

[12] N. W. Rajapakse, J. J. Oliver and R. G. Evans, "Nitric Oxide in Responses of Regional Kidney Blood Flow to Vasoactive Agents in Anesthetized Rabbits," Journal of Cardiovascular Pharmacology, Vol. 40, No. 2, 2002, pp. 210-219. doi:10.1097/00005344-200208000-00006

[13] J. J. Oliver, N. W. Rajapakse and R. G. Evans, "Effects of Indomethacin on Responses of Regional Kidney Perfusion to Vasoactive Agents in Rabbits," Clinical Experimental Pharmacology and Physiology, Vol. 29, No. 10, 2002, pp. 873-879.

doi:10.1046/j.1440-1681.2002.03742.x
[14] A. P. Zou, F. Wu and A. W. Cowley Jr., "Protective Effect of Angiotensin II-Induced Increase in Nitric Oxide in the Renal Medullary Circulation," Hypertension, Vol. 31, No. 2, 1998, pp. 271-276. doi:10.1161/01.HYP.31.1.271

[15] A. O. Oyekan, "Contributions of Nitric Oxide and Prostanoids and Their Signaling Pathways to the Renal Medullary Vasodilator Effect of U46619 (9-11-Dideoxy-11 $\alpha$, 9a-epoxymethano-prostaglandin F2a) in the Rat," Journal of Pharmacology and Experimental Therapeutics, Vol. 304, No. 2, 2003, pp. 507-512. doi:10.1124/jpet.102.040170

[16] J. L. Williams, D. Cartland, A. Hussain and S. Egginton, "A Differential Role for Nitric Oxide in Two Forms of Physiological Angiogenesis in Mouse," Journal of Physiology, Vol. 570, No. 3, 2006, pp. 445-454. doi:10.1113/jphysiol.2005.095596

[17] S. Crestani, Y. D. Rattmann, T. R. Cipriani, L. M. de Souza, M. Iacomini, C. A. Kassuya, M. C. Marques and J. E. da Silva-Santos, "A Potent and Nitric Oxide-Dependent Hypotensive Effect Induced in Rats by Semi-Purified Fractions from Maytenus Ilicifolia," Vascular Pharmacology, Vol. 51, No. 1, 2009, pp. 57-63. doi:10.1016/j.vph.2009.02.005

[18] H. C. D. Souza, H. C. Salgado, G. Ballejo and M. C. O. Salgado, "SR141716A-Sensitive Enhancement of ET-1 Hypotensive Effect by Chronic NOS Inhibition," Hypertension, Vol. 42, No. 2, 2003, pp. 802-805. doi:10.1161/01.HYP.0000088362.50484.4C

[19] L. M. Duke, G. A. Eppel, R. E. Widdop and R. G. Evans, "Disparate Roles of $\mathrm{AT}_{2}$ Receptors in the Renal Cortical and Medullary Circulations of Anesthetized Rabbits," Hypertension, Vol. 42, No. 2, 2003, pp. 200-205. doi:10.1161/01.HYP.0000083341.64034.00

[20] S. Y. Chou, J. G. Porush and P. F. Faubert, "Renal Medullary Circulation: Hormonal Control," Kidney International, Vol. 37, No. 1, 1990, pp. 1-13. doi:10.1038/ki.1990.1

[21] D. S. A. Majid, M. Godfrey and L. G. Navar, "Pressure Natriuresis and Renal Medullary Blood Flow in Dogs," Hypertension, Vol. 29, No. 4, 1997, pp. 1051-1057. doi:10.1161/01.HYP.29.4.1051

[22] S. A. Omoro, D. S. A. Majid, S. S. El-Dahr and L. G. Navar, "Kinin Influences on Renal Regional Blood Flow Responses to Angiotensin-Converting Enzyme Inhibition in Dogs," American Journal of Physiology Renal Physiology, Vol. 276, No. 2, 1999, pp. F271-F277.

[23] N. Parekh, L. Dobrowolski, A. P. Zou and M. Steinhausen, "Nitric Oxide Modulates Angiotensin II- and Norepinephrine-Dependent Vasoconstriction in Rat Kidney," American Journal of Physiology Regulatory Intergrative and Comparative Physiology, Vol. 270, 1996, pp. R630-R635.

[24] R. G. Evans, G. Bergstroł̀m and A. J. Lawrence, "Effects of the Vasopressin V1 Agonist [Phe2,Ile3,Orn8]-Vasopressin on Regional Kidney Perfusion and Renal Excretory Function in Anesthetized Rabbits," Journal of Cardiovascular Pharmacology Vol. 32, No. 4, 1998, pp. 571581. doi:10.1097/00005344-199810000-00009 
[25] L. G. Navar, B. L. Harrison, J. D. Imig, et al., "Role of AT1 Receptor in Target Organ Disease: A Functional Perspective," American Journal of Hypertension, Vol. 13, No. 1, 2000, pp. 45S-54S. doi:10.1016/S0895-7061(99)00248-4

[26] R. G. Evans, G. A. Head, G. A. Eppel, S. L. Burke and N. W. Rajapakse, "Frontiers in Research Series: Neural, Hormonal and Renal Interactions in Long-term Blood Pressure Control II: Angiotensin II and neurohumoral Control of the Renal Medullary Circulation," Clinical and Experimental Pharmacology and Physiology, Vol. 37, No. 2, 2010, pp. 58-69. doi:10.1111/j.1440-1681.2009.05233.x

[27] P. A. Ortiz, N. J. Hong, D. Wang and J. L. Garvin, "Gene Transfer of eNOS to the Thick Ascending Limb of eNOS-KO Mice Restores the Effects of L-Arginine on $\mathrm{NaCl}$ Absorption," Hypertension, Vol. 42, No. 4, 2003, pp. 674-679. doi:10.1161/01.HYP.0000085561.00001.81

[28] H. M. Siragy and R. M. Carey, "The Subtype-2 ( $\left(\mathrm{AT}_{2}\right)$ Angiotensin Receptor Regulates Renal Cyclic Guanosine 3,5-Monophosphate and $\mathrm{AT}_{1}$ Receptor-Mediated Prostaglandin $\mathrm{E}_{2}$ Production in Conscious Rats," Journal of Clinical Investigation, Vol. 97, No. 8, 1996, pp. 19781982. doi:10.1172/JCI118630

[29] M. D. Breyer and R. M. Breyer, "Prostanglandin E Recaptors and the Kidney," American Journal of Physiology, Renal Physiology, Vol. 279, No. 1, 2000, pp. F12- F23.

[30] A. Yared, V. Kon and I. Ichikawa, "Mechanism of Preservation of Glomerular Perfusion and Filtration during Acute Extracellular Volume Depletion: Importance of Intrarenal Vasopressin Prostaglandin Interaction for Protecting Kidneys from Constrictor Action of Vasopressin," Journal of Clinical Investigation, Vol. 75, No. 5, 1985, pp. 1477-1487. doi:10.1172/JCI111851

[31] F. G. Knox and J. P. Granger, "Control of Sodium Excretion: An Integrative Approach," In: E. E. Windhager, Ed., Renal Physiology, Oxford University Press, New York, 1992.

[32] J. Sadowski, E. Kompanowska-Jezierska, L. Dobrowolski, A. Walkowska and B. Badzynska, "Simultaneous Recording of Tissue Ion Content and Blood Flow in Rat Renal Medulla: Evidence on Interdependence," American Journal of Physiology Renal Physiology, Vol. 273, No. 4, 1997, pp. F658-F662.

[33] E. Kompanowska-Jezierska, A. Walkowska and J. Sadowski, "Exaggerated Volume Expansion Natriuresis in Rats Preloaded with Hypertonic Saline: A Paradoxical Enhancement by Inhibition of Prostaglandin Synthesis," Acta Physi- ologica Scandinavica, Vol. 167, No. 3, 1999, pp. 189-194. doi:10.1046/j.1365-201x.1999.00604.x

[34] H. G. Klieber and J. Daut, "A Glibenclamide-Sensitive Potassium Conductance in Terminal Arterioles Isolated from Guinea Pig Heart," Cardiovascular Research, Vol. 28, No. 6, 1994, pp. 823-830. doi:10.1093/cvr/28.6.823

[35] S. M. Gardiner, P. A. Kemp, J. E. March, B. Fallgren and T. Bennett, "Effects of Glibenclamide on the Regional Haemodynamic Actions of $\alpha$-Trinositol and Its Influence on Responses to Vasodilators in Conscious Rats," British Journal of Pharmacology, Vol. 117, No. 3, 1996, pp. 507515. doi:10.1111/j.1476-5381.1996.tb15219.x

[36] A. L. Salzman, A. Vromen, A. Denenberg and C. Szabo, "K $\mathrm{K}_{\mathrm{ATP}}-\mathrm{Channel}$ Inhibition Improves Hemodynamics and Cellular Energetics in Hemorrhagic Shock," American Journal of Physiology Heart Circulation Physiology, Vol. 272, No. 2, 1997, pp. H688-H694.

[37] T. Mimuro, T. Kawata, T. Onuki, S. Hashimoto, K. Tsuchiya, H. Nihei and T. Koike, "The Attenuated Effect of ATP-Sensitive $\mathrm{K}^{+}$Channel Opener Pinacidil on Renal Haemodynamics in Spontaneously Hypertensive Rats," European Journal of Pharmacology, Vol. 358, No. 2, 1998, pp. 153-160. doi:10.1016/S0014-2999(98)00573-1

[38] C. Cao, W. Lee-Kwon, E. P. Silldorff and T. L. Pallone, "K $\mathrm{K}_{\mathrm{ATP}}$-Channel Conductance of Descending Vasa Recta Pericytes," American Journal of Physiology Renal Physiology, Vol. 289, No. 6, 2005, pp. F1235-F1245. doi:10.1152/ajprenal.00111.2005

[39] M. DeGasparo, K. J. Catt and T. Inagami, "International Union of Pharmacology XXIII. The Angiotensin II Receptors," Pharmacological Reviews, Vol. 52, No. 3, 2000, pp. 415-472.

[40] H. Matsubara, T. Sugaya, S. Murasawa, Y. Nozawa, Y. Mori and H. Masaki, "Tissue-Specific Expression Of Human Angiotensin II $\mathrm{AT}_{1}$ and $\mathrm{AT}_{2}$ Receptors and Cellular Localization of Subtype mRNAs in Adult Human Renal Cortex Using in Situ Hybridization," Nephron, Vol. 80, No. 1, 1998, pp. 25-34. doi:10.1159/000045121

[41] L. M. Duke, R. E. Widdop, M. M. Kett and R. G. Evans " $\mathrm{AT}_{2}$ Receptors Mediate Tonic Renal Medullary Vasoconstriction in Renovascular Hypertension," British Journal of Pharmacology, Vol. 144, No. 4, 2005, pp. 486-492. doi:10.1038/sj.bjp.0706036

[42] R. E. Widdop, E. S. Jones, R. E. Hannan and T. A. Gaspari, "Angiotensin $\mathrm{AT}_{2}$ Receptors: Cardiovascular Hope or Hype?" British Journal of Pharmacology, Vol. 140, No. 5, 2003, pp. 809-824. doi:10.1038/sj.bjp.0705448 